\title{
高齢者の咽喉頭異常感と嬩下機能
}

\author{
可世木由美子，棚 橋 汀 路 \\ 松井岳仁，柳田 則之
}

\section{Abnormal Sensation in the Pharyngo-laryngeal Region of Senile Patients}

\author{
Yumiko Kaseki, M.D., Teiji Tanahashi, M.D., \\ Takehito Matsui, M.D., and Noriyuki Yanagita, M.D. \\ Department of Otolaryngology, Nagoya University, School of Medicine, Nagoya
}

\begin{abstract}
The causative lesion in patients complaining of abnormal sensation in the throat is often obscure because of the difficulty in precise diagnosis. Swallowing function is thought to deteriorate with age from normal to i) a feeling of an abnormal throat sensation, and ii) a frank swallowing disorder. Patients were categorized age-wise, into three main groups, i) $40^{-}$ 50 , ii) 50-60 and iii) 60 and above. In the last group were included controls. Pharyngo-larynx was examined by laryngoscopy and contrast barium studies. Compared to the patients in the younger age groups, some patients above 60 years were found to have a higher incidence of inflammatory lesions in the laryngopharynx, barium retention in the piriform sinus, vallecular space and the supra-glottic surface of the cords; a few had slight aspiration of the barium. Patients in the 60-above group showed improvement in their swallowing with drugs which improve cerebral metabolism and circulation. It was found that adding this therapy improves abnormal throat sensation in those senile patients who had swallowing dysfunction. In conclusion, there appear to be a high rate of functional swallowing disturbance among senile patients with abnormal sensation in the throat.
\end{abstract}

Key words：咽喉頭異常感，黇下機能，誤嚥の薬物治療

\section{はじめに}

咽喉頭異常感を主訴とする患者には，原因と なる器質的疾患がはっきりしないことが多い。 しかし，その中には観察しがたい原因疾患が潜 在する可能性が高い1。異常感患者の診察にあ たつて，直接または間接的にみる咽喉頭異常所 見には常に注意しているが，そこが日々行われ

名古屋大学医学部耳鼻咽喉科学教室

別刷請求: $\mathbf{T} 466$ 愛知県名古屋市昭和区鶴舞町 65 名古屋大学医学部耳鼻咽喉科学教室 可世木由美子

投稿受付：1989年 6 月 15 日
ている嚥下の場であり，その影響を受けている ことを，われわれは忘れがちに思う。今回，特 に咽喉頭異常感を訴える高齢の患者について, その原因がさまざまな局所的, 全身的要因とと もに, 嬩下機能障害に起因することの多いこと, そしてそのためにこれらの治療には, 単に局所 の治療にとどまるのでなく, 嚥下機能改善に留 意しなくてはいけないことを述べてみたい。

\section{方法}

対象は, 昭和 60 年 1 月より 63 年 4 月までに当 科に咽喉頭異常感を主訴として来院した60歳以 上58名, 40歳代76名, 50歳代35名である (表 1 )。 
表 1

\begin{tabular}{c|c:c|c:c|c|c|c}
\hline & 40 歳代 & 50 歳代 & 60 歳代 & \multirow{2}{*}{ 計 } \\
\cline { 2 - 6 } & 男 & 女 & 男 & 女 & 男 & 女 & \\
\hline 総 調 查 数 & 28 & 49 & 12 & 23 & 29 & 29 & 170 \\
\hline 食道造影施行者 & 11 & 16 & 6 & 11 & 20 & 20 & 84 \\
\hline
\end{tabular}

\section{表 2 咽喉頭所見の内訳}

\begin{tabular}{|c|c|c|c|c|c|c|}
\hline & \multicolumn{2}{|c|}{ 40歳代 } & \multicolumn{2}{|c|}{ 50歳代 } & \multicolumn{2}{|c|}{ 60歳以上 } \\
\hline & 男 & 女 & 男 & 女 & 男 & 女 \\
\hline 正 & 19 & 36 & 8 & 18 & 7 & 6 \\
\hline 舌根扁頭肥大 & 5 & 10 & 4 & 4 & 4 & 7 \\
\hline 仮声帯肥大 & 0 & 1 & 0 & 0 & 3 & 3 \\
\hline 声帯腫脹 & 0 & 0 & 1 & 0 & 3 & 3 \\
\hline 声帯の動きの低下 & 0 & 0 & 0 & 1 & 1 & 1 \\
\hline 喉頭発赤 & 1 & 1 & 1 & 0 & 5 & 7 \\
\hline 声帯ポリープ & 0 & 0 & 0 & 1 & 0 & 0 \\
\hline 梨状陥凹の唾液貯留 & 0 & 1 & 0 & 2 & 10 & 2 \\
\hline
\end{tabular}

表 3 食道造影異常所見の内訳

\begin{tabular}{|c|c|c|c|c|c|c|}
\hline \multirow[b]{2}{*}{ 調 査 数 } & \multicolumn{2}{|c|}{ 40歳代 } & \multicolumn{2}{|c|}{ 50歳代 } & \multicolumn{2}{|c|}{ 60歳代 } \\
\hline & $\begin{array}{l}\text { 男 } \\
\text { (11) }\end{array}$ & $\begin{array}{l}\text { 女 } \\
\text { (16) }\end{array}$ & $\begin{array}{l}\text { 男 } \\
\text { (6) }\end{array}$ & 女 & $\begin{array}{c}\text { 男 } \\
(20)\end{array}$ & $\begin{array}{c}\text { 女 } \\
\text { (20) }\end{array}$ \\
\hline 咽頭内貯留 & & & & & & \\
\hline (1)喉頭蓋谷の残留 & 2 & 1 & 3 & 1 & 15 & 9 \\
\hline (2)梨状陥凹の貯留 & 0 & 3 & 0 & 1 & 14 & 6 \\
\hline (3)喉頭前庭への侵入 & 0 & 0 & 0 & 0 & 9 & 5 \\
\hline 非対称嚥下 & 1 & 1 & 0 & 0 & 1 & 0 \\
\hline 誤 嶼 & 0 & 1 & 0 & 0 & 3 & 1 \\
\hline 鋸歯状収縮 & 0 & 0 & 0 & 0 & 5 & 5 \\
\hline
\end{tabular}

これらの患者について咽喉頭局所異常所見を検 討する（表 2 ）とともに，食道造影を行いえた 者について，その異常所見を比較検討した（表 3 )。また異常感を訴えない60歳以上の volunteer 30名について, 食道造影を行いコントロー ルとした(表 4 )。さらにこれら高齢者の異常感 患者に嶼下治療を加えることにより，その治療 効果および食道造影所見の変化を検討した（表 5 )。
表 4 60歳以上における食道造影異常所見の内訳

\begin{tabular}{|c|c|c|}
\hline 対象者数 & $\begin{array}{c}\text { 咽喉頭異常 } \\
\text { 感患者 } \\
(40) \\
(\%) \\
(\%)\end{array}$ & $\begin{array}{c}\text { コントロール } \\
(20) \\
(\%)\end{array}$ \\
\hline 咽頭内貯留 & & \\
\hline (1)喉頭蓋谷残留 & $24(60.0)$ & $7(35.0)$ \\
\hline (2)梨状陥凹貯留 & $20(50.0)$ & $6(30.0)$ \\
\hline (3)喉頭前庭侵入 & $14(35.0)$ & $0(0.0)$ \\
\hline 非対称嚥下 & $1(2.5)$ & $0(0.0)$ \\
\hline 詔 嚥 & $4(10.0)$ & $1(5.0)$ \\
\hline
\end{tabular}

表 5 咽喉頭異常感患者における治療前後の比較

\begin{tabular}{|c|c|c|c|c|}
\hline $\begin{array}{l}\text { 喉 } \\
\text { 頭 } \\
\text { 圔 } \\
\text { 残 } \\
\text { 留 }\end{array}$ & $\begin{array}{r}\text { 梨 } \\
\text { 桨 } \\
\text { 陷 } \\
\text { 留凹 }\end{array}$ & $\begin{array}{l}\text { 喉 } \\
\text { 頭 } \\
\text { 侵前 }^{\text {庭 }}\end{array}$ & $\begin{array}{l}\text { 誤 } \\
\text { 嚥 }\end{array}$ & $\begin{array}{l}\text { 翡 } \\
\text { 対 } \\
\text { 称 } \\
\text { 鮞 }\end{array}$ \\
\hline$+\rightarrow-$ & $+\rightarrow-$ & $+\rightarrow-$ & $+\rightarrow-$ & - \\
\hline$+\rightarrow-$ & $+\rightarrow-$ & $+\rightarrow-$ & - & - \\
\hline$+\rightarrow-$ & - & $+\rightarrow-$ & $+\rightarrow-$ & - \\
\hline- & $+\rightarrow-$ & $+\rightarrow-$ & - & - \\
\hline+ & $+\rightarrow-$ & + & + & - \\
\hline$+\rightarrow-$ & - & - & - & - \\
\hline+ & $+\rightarrow-$ & - & - & - \\
\hline+ & $+\rightarrow-$ & - & - & - \\
\hline+ & + & + & + & - \\
\hline+ & + & + & $\rightarrow \rightarrow+$ & $+\rightarrow-$ \\
\hline- & - & - & - & - \\
\hline- & - & - & - & - \\
\hline
\end{tabular}

\section{結果}

表 2 は, 異常感患者の咽喉頭局所異常所見の 年代性別頻度を示す。特徵的なことは高齢者に おいて, 局所炎症所見出現頻度が高いとともに, 梨状陷凹の唾液貯留の出現が多いことである。

表 3 は, 食道造影を行いえた者 84 名の異常所 見 ${ }^{2)}$ 出現数を示す。60歳以上の高齢者群では, 明らかに喉頭蓋谷に残留のみられた者が男女各 20 例中男15例, 女 9 例, 梨状楩凹の貯留の見ら れた者が, 男14例, 女 6 例, さらに喉頭前庭に 
日気食会報，41（1），1990

まで侵入をみたものが，男 9 例，女 5 例と他の 年齢層に比較して多かった。さらに異常感のみ でなんら誤嬩症状を訴えない者にも少量の誤嚥 を認めた者が，高齢者において 4 例（男 3 例女 1 例）見い出しえた。

表 4 は, 60歳以上の食道造影異常所見を異常 感患者と, 異常感を訴えない者との比較を示し た。喉頭蓋谷貯留は，コントロール $35 \%$ に対し 異常感患者では $60 \%$, 梨状楩凹貯留は, コント ロール $30 \%$ に対し $50 \%$ ，喉頭前庭侵入が，コン トロール $0 \%$ に対し $35 \%$ と，大いに異常がみら れた。

表 5 は, 60歳以上の異常感患者で, 曣下治療 を行い追跡可能であった症例の食道造影所見の 推移を示した。これらの症例は全例, 局所治療 と共に嚥下治療を行うことにより異常感の改善 をみた。表で見られるごとく, 食道造影異常所 見も十から一へ改善を見た者が比較的多かっ た。

図 1，2 は咽喉頭異常感を主訴に来院した64 歳女性の食道造影写真である。この症例は，近 医で咽喉頭異常感症として数力月間抗炎症等の 局所治療を受けていたが, 症状が改善しないた めに来院した。咽喉頭に軽度炎症所見をみる以 外, 特に器質的障害を認めなかった。初診時食 道造影では, 図 1 で示すごとく気管内大量誤嚥 がみられ, 咽喉頭異常感症というよりは誤嬩症 例である。この患者に, 食事時できるだけ嚥下 することに注意させようとする精神集中療法 と, 脳代謝改善剂, 循環改善剂等を投与した。 その 1 週間後, 異常感の改善をみると同時に図 2 で示すごとく食道造影所見で気管内誤嶼の著 明改善をみた。

\section{考按}

咽喉頭異常感を訴える患者には，直接原因と なる器質的疾患を認めるものと, 器質的疾患が 認められてもそれが原因とは考えがたいもの， 器質的疾患を認めないのに異常感を訴えるもの とがある。器質的疾患が認められないものの多 くは, 直接には認め難い疾患が潜在する可能性 が高い。

咽喉頭は，呼吸，嚥下，発声という複雑な機 能の場であり，それだけにこの場の異常を考え

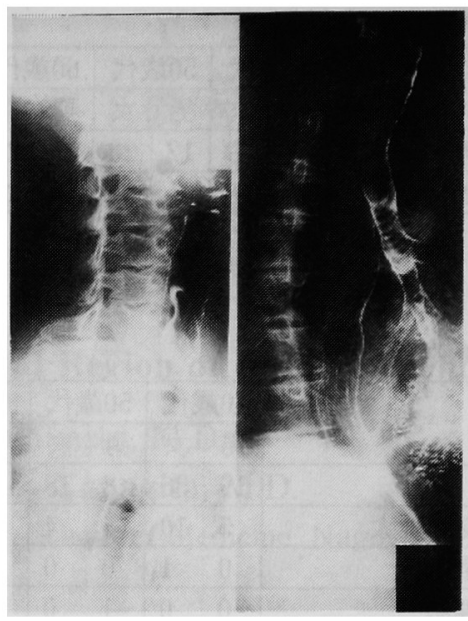

図 1

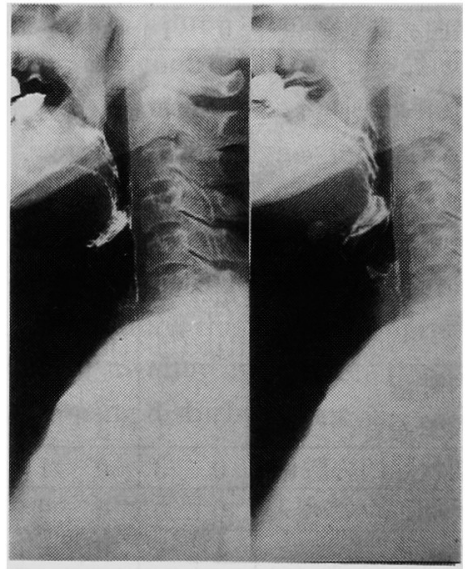

図2

る時, 種々の角度からとらえなければならない。 われわれ臨床医にとっては, 直接観察しうる静 的異常所見には留意しやすいが，特に日常の外 来診察では直接見ることの難しい嶼下機能異常 については，しばしば忘れがちに思う。特に高 齢者では, 咽喉頭異常感のみでなんら誤曣症状 のないにもかかわらず食道造影により嚥下障害 を認めることが多いこと，また明らかな気管内 誤嚥下を認めなくても, 異常感の原因が嬩下機 能障害と関与していると考えられる症例が多い ように思う。

佐々木ら ${ }^{31}$ は，なんら愁訴のない正常の高齢 者において, 咽頭内貯留所見は高頻度に認めら 
れると言い,このために木内ら ${ }^{4)}$ は, 咽喉頭異常 感症例で本現象が観察されても，異常感との間 に特別の意味をつけることは困難であると述べ ている。

しかしわれわれの結果によると，高齢者の異 常感患者では局所炎症所見を示す比率が他の年 代に比べて高く，それとともに食道造影所見で 喉頭蓋谷の残留, 梨状陥凹の貯留, 喉頭前庭へ の侵入等の咽頭内貯留所見の増加をみた。また これら食道造影異常所見は, 同年代の異常感を 訴えない正常者群と比べて出現頻度が高かっ た。このことは，これら異常感患者の多くの者 に誤睘予備群と考えられる者が存在する可能性 の高いことを示唆する。

睘下機能の破綻は, やがては咽喉頭に慢性炎 症等の二次的器質的障害5をもたらすであろう が，これらの治療にあたる時，もしその局所治 療にしか留意しないのであれば片手落ちに思 う。この場合, 必ず嚥下機能改善にも努めなけ ればならない。事実, 表 5 で示すがごとく, こ れら異常感患者に抗炎症等の局所治療の他に食 事時の嶼下に対する精神集中療法及び中枢性循 環，代謝改善剂投与を主体とする嬩下治療(6) 行ってみると症状の改善, および食道造影所見 の改善を多くみた。また図 1 , 図 2 で示した誤 曖症例でも同様な治療で効果が認められた。こ のように何ら他に神経症状を認めない嶼下障害 患者7や, 異常感症例の中のいわゆる誤嚥予備 群と考えられる患者は，これら薬物療法の良い 適応であると思われる。このことは高齢者の嬹 下障害，および異常感の原因の多くは，年齢に 伴う動脈硬化あるいは萎縮の進行による咽喉頭 知覚低下, 咽喉頭筋層障害というょりは, 中枢 性に制御された一連の運動による嬩下機能の破 綻と考えられる。

高齢者は, 愁訴を正しく表現し難い者も多く， さらに他の器質的異常の出現も高いために, 適
確な対処を誤ることもしばしばある。われわれ は高齢者の異常感患者を考える時，特に嬩下障 害の潜在に留意しなくてはならない。

\section{結語}

高齢者の咽喉頭異常感患者について，局所異 常所見，食道造影所見を他の年代のそれと比較 し，また異常感を訴えない正常の高齢者群の食 道造影所見とも比較して以下の結論を得た。

1) 高齢者の異常感患者では，局所炎症所見 の存在および食道造影において，喉頭蓋谷の残 留, 梨状陥凹の貯留, 喉頭前庭への侵入等の咽 頭内貯留所見を高率にみた。そしてこれら食道 造影異常所見は同年代の異常感を訴えない正常 者群と比較しても多く認めた。

2 ）これら高齢者の異常感患者に食事時の精 神集中療法および脳代謝改善剂, 脳循環改善剂 等の投与を含めた嚥下治療および抗炎症等の局 所治療を行うことにより全例症状の改善をみ た。

3 ）このことは高齢者の異常感患者の多くの ものに, 嚥下障害の潜在 (誤嚥予備群) を示唆 するものであった。

\section{文献}

1) 平野 実：咽喉頭異常感症。耳鼻臨床，70：997, 1977.

2 ) 木内宗甫：誤嚥のX線診断のこつ。日気食会報, $31: 135-137,1980$

3 ）佐々木順三：咽頭, 食道機能異常の臨床的観察. 日耳鼻, $70 ： 1639-1650,1967$.

4 ）木内宗甫, 正来秀也, 長谷川浩通：X線透視上 りみた咽喉頭異常感。耳侯, $40: 551-557,1968$.

5 ) 木内宗甫：嬿下障害の臨床的観察.日耳鼻, 81 : $569-577,1978$

6 ）棚橋汀路：臙下障害及び聴力障害例でのエンポ 一ル使用経験。診療, 23：190-194, 1970.

7 ) 藤 雄一：脳血管障害症例の嚥下動態。耳鼻, 28:1126-1160, 1982. 